\title{
Thomas Phaer and the Assertion of Tudor English
}

RICK

BOWERS

Summary: Thomas Phaer's many printed works, including legal and medical texts, occasional verses, and classical translations, all insist upon - even assert - English as a language suitable for learned consciousness. As a physician, legal theorist, man of letters, and member of Parliament, Phaer represents a new English praxis of cultural and intellectual communication. His life and work are centered in the vicissitudes of Tudor polity, wherein he works to mobilize the vernacular and, in so doing, assert early modern English culture.

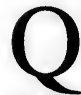

uestioned by a learned ecclesiastic concerning his translation of the Bible into English, William Tyndale defied his inquisitor as follows: "If God spare my life, ere many years I will cause a boy that driveth the plough shall know more of the Scripture than thou doest." What impresses a reader at the end of the twentieth century about Tyndale's riposte is its radical defiance, its extreme collision of spiritual value and class assertion within the powerful vernacular of early modern English. This same sense of vernacular mission saw Tyndale, condemned as a heretic in 1536 , embracing the stake while imploring in English, "Lord, open the King of England's eyes."2 Henry VIII's eyes were "opened," and less than a year after Tyndale's execution the Bible in English was legally authorized for use in churches by the new Supreme Head of the Church in England.

What all this must have meant personally for a young intellectual such as Thomas Phaer (c. 1510-1560), coming into maturity in this period, is difficult to determine. But what Tyndale did for English Protestant theology, Phaer 
would do for English multidisciplinary professional education. His various works include an early translation of The Aeneid (that key text of British etiology, completed of necessity after his death), English legal texts such as $A$ Newe Boke of Presidentes (either written by Phaer or directly connected to him), a popular translation of the French medical text entitled The Regiment of Lyfe (appropriated for a distinctly English readership), and the first text on pediatrics ever to be written in English: The Boke of Chyldren (1544), wherein Phaer rhetorically demands of Latinist physicians: "How long wold they have the people ignorant? why grutche they phisyke to come forth in Englyshe? woulde they have no man to know but onely they?" 3 Thus the voice of new learning in Tudor England: an insistent voice that is confidently dissident in tone and politically certain of its own vernacular.

A hundred years after his death in August 1560, Thomas Phaer was still remembered by the Oxonian biographer and historian Anthony à Wood as "a person of a mutable mind." "Scientist, classicist, physician, legal theorist, member of Parliament, and general man of letters, Phaer certainly followed a mutable and nontraditional career pattern. Put simply, he was a Renaissance polymath. But he was not born whole into the world of Tudor England. Neither his date nor place of birth are known for certain. Nor is his time at Oxford officially recorded. And yet this little-known figure influentially informs and is informed by the social, cultural, and intellectual forces of sixteenth-century England, forces which, in a new age of self-conscious professionalism, also ensure his obscurity. Phaer informs readers across learned disciplines, where his transformative effect as educator is more significant than either his personal biography or his specific publications. And all his published endeavors in medicine, poetry, law, and classical learning are linked by a reliance - even an insistence - on English as his preferred mode of scholarly communication.

This essay foregrounds Thomas Phaer's The Boke of Chyldren because of its unprecedented nature as the first English pediatrics text. But it, like Phaer's other publications in medicine, law, and the classics, is also a cultural text that advocates and asserts English as a language suitable for learned consciousness. Herein Phaer displays a profound mobility of intellect which he transposes onto his various subjects for the purposes of information. His multidisciplinary approach is as transformative intellectually as it is linguistically empowering. Moreover such English self-fashioning power, as noted by Greenblatt, ${ }^{5}$ occurs in relation to a hostile alien force, a threatening other - in this case, Latin, foreign languages generally, and those who would accrue power by maintaining the ignorance of English people. But that same English populace, Phaer's 
readership, also acts as discursive other for the cultural formations presented by Phaer through vernacular English publication. Throughout his career, Phaer insists on an achieved cultural identity that is English and authoritative.

Phaer is clearly in touch with the social and political vicissitudes of his day, and this familiarity perhaps explains in some measure his various public positions and responsibilities. He operated within a cultural establishment at once respected but also under a great deal of social stress. Indeed any establishment was threatened in the reformation and counter-reformation climate of early Tudor England. Hence, perhaps, Phaer's later politic decampment to Wales, to its relatively safe marginality, its rural complacency, its fundamentally Tudor allegiance. And his medical consciousness was determined in no small bit by an interactive social order reliant on native English. This period in England charted a cultural shift from a priest class chanting Latin repetitions to protestant vernacular texts having to do with thesis, analysis, and active persuasion. The rise of the printed text nourished an unprecedented instructional culture, a culture informed by biblical and humanist texts but also by a myriad of more popular texts on theorized religious discipline, folk and medical remedies, and occult events and happenings. These books - and The Boke of Chyldren represents a significant example in its rehearsal of remedies and medicaments - were informative, not catechismal, vernacular, not Latin, social, not sacred. Such changes in emphasis and approach signal changes in the general social orientations of academic life that informed Thomas Phaer: from the analogical to the empirical, from a medieval love of patterning to a Renaissance discourse of exploration, discovery, and dissemination.

In their cultural assertiveness, authoritative certainty, and printed stability as "English" learning, Phaer's books both define and benefit from an incipient and unstable cultural nationalism. His use of the vernacular democratizes learning across disciplines, where English is asserted as means to cultural advancement and cultural definition. And the power of the printed word flexes remarkably in this early period of publication and information transferral. In her rich study, The Printing Press as an Agent of Change, Eisenstein notes the power of print dissemination but also of intellectual cross-fertilization and cultural exchange afforded by the printed text. ${ }^{6}$ Clearly Phaer, broadcasting information in printed English as opposed to guarding it in specialized academic language, is very much a creature of print culture. And print, as the invention that actually advertises itself, advertises itself in unstable relation to its own vernacular. Hence "English" becomes a published national consciousness. 
Phaer's The Boke of Chyldren is itself listed as one of the thirteen "Medical best-sellers 1486-1604" in Paul Slack's essay on vernacular medical literature in Tudor England. ${ }^{7}$ Prior to linguistic reformers such as Tyndale and Phaer, the informed language of the English mind involved nonpopular foreign languages. Phaer's exterior concern with popularizing English meshes with an interior concern for shaping English consciousness in opposition to the threat of other languages and in defiance of a system that mystifies learning through class domination. His preface to The Boke of Chyldren itself reads like a polemic, restating Tyndale's challenge in populist cultural terms:

My purpose is here to doo theym good that have moste nede, that is to saye, children: and to shewe the remedies that god hath created for the use of man, to distribute in engylshe to them that are unlearned, parte of the treasure that is in other languages, to provoke them that are of better learnyng, to utter their knowledge in suche lyke attemptes: fynally to declare that to the use of many, whyche oughte not to be secrete for lucre of a fewe (p. 13).

Clearly, Phaer's mission is to popularize pediatric care and inform his fellow citizens of health care issues specific to the treatment of children. English, not Latin, is valorized as the language proper to informing English parents. Phaer probably felt licensed in his criticism by Sir Thomas Elyot's defense of the vernacular a few years earlier in The Castel of Helth: "But if phisitions be angry, that I have wryten phisike in englyshe, let theym remembre that the grekes wrate in greke, the Romanes in latyne, Avicena and the other in Arabike, whiche were their owne propre and maternal tonges." Phaer rehearses a similar line of argument in his own preface to The Boke of Chyldren, but cannot restrain himself from the following preemptive strike against Latinists:

Christe sayth: No manne lyghteth a candell to cover it with a bushell, but setteth it to serve every mans nede: And these [Latinist writers] go about, not onely to cover it when it is lyghted, but to quenche it afore it be kyndled (yf they myght by malice) which as it is a detestable thynge in any godly science: so me thynketh in this so necessary an arte, it is excedying damnable and dyvelyshe (p. 14).

Note the demonizing of Latin mystification, defined by Phaer as specifically malicious. He scorns erudition masked by foreign cachet as much as he scorns the conventional modesty formulas with which such erudition typically presents itself. Phaer's truculent cultural challenge and spiritual assertion played well in England in the first half of the sixteenth century, a period which had seen popular translation of Scripture into English by Tyndale and Coverdale 
in 1525 and 1535 respectively, and had also experienced the rigorous social consolidation of the realm under Henry VIII as a religious and cultural entity detached from continental Europe.

Thomas Phaer presents himself as very much a middle-class Tudor man of a conservative temperament with distinctive scholarly abilities and stronglyconceived public responsibilities. Yet, as noted previously, little is known for sure about his early life. He may have been born in Norwich sometime in 1510 or thereabouts, and was educated at Oxford University and at Lincoln's Inn. ${ }^{9}$ His early residence in the household of William Paulet, First Marquess of Winchester, no doubt helped his career advancement in law and politics and may have secured for him his appointment as solicitor to the council of the Marches of Wales. Phaer says nearly as much in his dedication to Queen Mary of the first seven books of the "Eneidos of Virgill," printed in 1558: "I have been preferred to your service by your right noble and faithfull counsailour Willyam lorde Marqueis of Winchester, my firste brynger up and patrone." ${ }^{.0}$ By this point, however, Phaer's authority and popularity were grounded in his reputation as a learned author and legislator. Necessarily rooted in patronage, he thrived on the widely-informed creation and dissemination of the vernacular word.

Phaer seems to have first appeared in print some 20 years earlier with the publication of a legal text entitled Natura Brevium. Newly Corrected in Englysshe (1530?). His name, at least, has always been popularly associated with this otherwise anonymous volume, the STC according him the status of translator. "Significantly this first publication would also be the last time that Latin was featured in a Phaer title, and even it, as noted in the title itself, is "corrected." This, he followed with a comprehensive formula book of legal documents and precedents entitled A Newe Boke of Presidentes (1543), concluding his preface with an egalitarian nod in the direction of the vernacular and with a distinct consciousness about the education of children:

And therfore is it compounded both in English and in Latyne, to the intent it may be the easelyer taken and perceyved of them that are but meanely learned in the Latyne tonge, and also for suche as wyll applye theyr chyldren to the readynge and understandyng of common evydences and wrytynges. Wherin Ibeseche God that they maye procede both to theyrowne commodytie, and profyte of theyr poore neyghbours. ${ }^{12}$

Even here, early in his career, Phaer asserts the facilitation and popularization of English within the learned discipline of Law. Previously a good Latin prose style was to be cultivated in the interests of public service, but Phaer insists that 
public service be rendered in vernacular English. And English would be the way of the future. Phaer's accessible legal text was so popular that it went through 27 editions to 1656 and was used by the great Elizabethan jurist Thomas Egerton when he was a student at Lincoln's Inn. ${ }^{13}$ Certainly Phaer's legal expertise prepared him for a career on the bench and in Parliament even though Fuller, in his History of the Worthies of England contends that "the Study of the Law did not fadge well with him, which caused him to change his copy, and proceed Doctor in Physick." ${ }^{14}$ In fact Phaer seems to have combined his professional intellectual pursuits in the law with a distinctly social concern that would move him into medical publication, literary activity, and active political involvement over a lifetime in English letters.

The year 1544 saw Phaer's translation of Jehan Goeurot's medical compendium The Regiment of Lyfe out of French and into the company of Phaer's own medical efforts: A Goodly Bryefe Treatyse of the Pestylence, A Declaration of the Veynes, and as previously noted The Boke of Chyldren. The octavo, containing all fourtitles, was printed in London by Edward Whytchurche, and exists today in a single copy at the Huntington Library. ${ }^{15}$ Phaer's was clearly a populist mission of education and concern, picking up where Latin authorities had left off, as set forth in the preface to his treatise on pestilence:

This disease when it ones beginneth enfecteth none so moche as the common people, among whom it is not gyven to al men to understande the forsayd volumes, yf they had them present, moch lesse can they get theyr health by theyr owne ymaginacions or experimentes, specially when almost no phisition wyll vouchesafe to visite any suche infected of the common sorte (so great is the daunger of this cruell syckenes) by reason wherof the pacientes cast themselves oftentymes into despeyre. ${ }^{16}$

Combine this with Phaer's avowed purpose in The Boke of Chyldren, "to doo theym good that have mooste nede" (p. 13), and one begins to detect a real sense of medical compassion, public spirit, national pride, and social responsibility in this widely-informed author. Of course altruistic prefaces also advertise self, and impersonal publication suggests an image of the author which may or may not coincide with lived actuality. But through publication, Phaer enters into a life of public image and cultural involvement.

Medical historian John Ruhräh calls Phaer the "Father of English Pediatrics," and modern Eneidos editor Steven Lally refers to him as "a humanist and avant-garde scientific mind."17 Phaer's humanism, however, was not of the academic variety of Erasmus, or John Colet. Instead he was publicly engaged, was busy in the day-to-day practice of law and medicine and 
as public representative and government agent. Indeed Phaer eschews classical academic debate in itself to present an interventionist public stance, a stance of populist social concern across disciplines with an especial regard for children. As published authority, he no doubt lived an image beyond personal circumstances of interaction. Can it be a complete coincidence that in 1547, during Phaer's first term as member of Parliament for the Welsh constituency of Carmarthen Boroughs, a bill "for the nursing of Children in Wales" should be introduced? ${ }^{18}$

Phaer served four terms under three monarchs as an M.P. from Wales, representing first Carmarthen Boroughs in 1547 before being returned from Cardigan Boroughs in 1555, 1558, and 1559. A fortunate marriage to widow Anne Revell no doubt aided him in taking a 21-year lease of demesne lands of the lordship of Cilgerran in November 1549. From this point on, Phaer made his permanent address in the forest of Cilgerran. This would be his home constituency. His leased property overlapped into Pembrokeshire, but Phaer was considered a Cardiganshire resident. His residence and prominence no doubt explain his nomination as sheriff for the region in 1552. Although, as noted in the Calendar of Patent Rolls the following year, another name was "pricked by the king as chosen," Phaer went on to serve the region in a variety of official capacities. ${ }^{19}$ And yet he seems to have been less than sanguine about his constituency, to judge by the citation in Bindoff's The House of Commons 1509-1558:

Cardiganshire was enlarged and consolidated at the Union. Thomas Phaer described it as "very bare ... and mountainous, all along the coast no trade of merchandise but all full of rocks and dangers." The few roads were unmetalled and travellers were vexed by bandits who the president of the council in the marches thought had the support of the local gentry. ${ }^{20}$

Clearly, this country doctor and legal man was in touch with his rural environment although, according to medical historian Robert Gottfried, Phaer's rural location was very unusual for a medical writer of the early Renaissance when most physicians lived either in London or in one of the university towns. ${ }^{21}$ As a widely published and actively political figure, however, Phaer may very well have craved a modicum of geographical inconspicuousness.

Throughout the 1550s Phaer served publicly as steward of Cilgerran and constable of the castle there, as crown searcher and customs officer in the port of Milford Haven, as solicitor to the council in the marches of Wales, and as Justice of the Peace for Cardiganshire. He would be well remunerated for these 
official duties, while a position in coastal customs would ensure an almost unlimited opportunity for graft. Yet Phaer seems to have been trusted throughout. On orders from the Marquess of Winchester, he prepared a report on harbors and customs administration in Wales, a report enrolled after his death on Queen Elizabeth's memoranda roll for Hilary term 1562). ${ }^{22}$ Although a loyal public servant under Mary, Phaer enjoyed the trust of Elizabeth's new administration as well, and his name is listed on the Pardon roll for the first year of Elizabeth's reign: "Thomas Phaer late of Kylgerran, co. Pembroke, alias M.D." (CPR $1558-60$, p. 203). His inclusion is a formality - but an obligatory one for anybody seeking government commission or public trust.

This lawyer, physician, and public administrator also thrived within the cultural constituency of the printed word, and it is perhaps through his early translation of The Aeneid that he is best known. Other translators such as Gavin Douglas, the Earl of Surrey, and Richard Stanyhurst had offered the poem in English, but Phaer's Eneidos, completed by Thomas Twyne and running to unprecedented multiple editions, can rightly be called "the Aeneid of the English Renaissance." ${ }^{23}$ Certainly Phaer was the first Englishman to attempt a translation of the entire epic, although his death prevented him from seeing the project to its conclusion. Keeping close account of time he spent translating, Phaer began his Eneidos on May 9, 1555, and averaged about twenty days work per book, work which he considered to be, in his words, "my pastyme in all my vacations" (Eneidos 1558, A2 ${ }^{\mathrm{r}}$ ). But such offhandedness represents a common contemporary trope of nonprofessional modesty that only accentuates the actual professionalism involved. Phaer's assertion of English was clearly a life project. He published The seven first bookes of the Eneidos of Virgill in 1558, followed by an edition of the nine first books after his death, brought out in 1562 by fellow M.P., William Wightman. It was not until 1584 that the entire Eneidos was completed by Twyne. But Phaer's nationalist perspective on the English language is in evidence from the very first, declaring his Virgil to be a "defence of my countrey language which I have heard discommended of many, and estemyd of some to bee more than barbarous (Eneidos $1558, \mathrm{X} 2^{\mathrm{r}}$ ).

If Phaer seems a bit truculent on the topic of his Englishness, bear in mind that assertion of the vernacular across disciplines had been his personal mandate for some 15 years. This, coupled with political involvement in Parliament and cultural advocacy in general, distinguishes Phaer as an especially informed and active contributor to Tudor cultural life. Even his first published poem took the form of a cultural defense and polemic thrust, 
appearing as preface to Peter Betham's translation of Jacopo di Porcia's The Preceptes of Warre (1544). The text's printer, Edward Whytchurche, had brought out Phaer's Newe Boke of Presidentes the year before, and was probably preparing the Regiment of Lyfe compendium for the press at the same time as he was printing Betham's work. In any case, Phaer's rhyme royal stanza for The Preceptes of Warre was as vaguely donnish as culturally defensive for a man embarking on a life of politics and publication:

Chyefest is peace, but yf by extremitye

Thou be enforced to fyght for thyne owne,

Learne here the science and actes of chyvaldrye,

Pollicies, and privities, to many men unknowen:

Wherby thyne enemyes may be overthrowen.

In suche a necessitie shalt thou never fynde

Suche an other treasure: kepe it wel in minde. ${ }^{24}$

A man who would thrive publicly under the Tudor administrations of midsixteenth-century England had better be politic, defensive, and clear-headed about the precepts of institutional debate, civic struggle, and open public conflict.

At about the same time as Phaer was preparing his Eneidos, He also contributed a poetic piece on Welsh hero Owen Glendower to The Mirror for Magistrates compendium. Entitled "Howe Owen Glendour seduced by false prophesies tooke upon him to be prince of Wales," this cautionary moral poem contains 34 verses which are vaguely Spenserian in form. Phaer was associated in this effort with contributors George Ferrers and Sir Thomas Chaloner, fellow M.P.'s, and probably knew Mirror compiler William Baldwin through Edward Whytchurche, in whose printing house Baldwin had worked. The 1578 edition of the Mirror contains William Baldwin's note of editorial facetiousness at the conclusion of Phaer's poem: "Whan mayster Phaer had ended the Tragedy of thys hunger starven Prynce of Wales, it was well liked of all the company that a Saxon would speake so mutch for a Brytton, then sodenly one found." 25 Phaer, however, although born a "Saxon" was now a Welsh resident and had represented his region publicly for years. He clearly had gained an adopted "Welshness" about himself, a cultural capacity that set him apart and perhaps aided his contemporary reputation for poetry.

And his poetic ability was clearly recognized, as noted by Anthony à Wood: "he was much famed among the academicians for his sufficiencies in the art of poetry" (p. 316). Indeed in 1589 no less an authority than George Puttenham, in The Arte of English Poesie, looked back a generation in 
considering "the most commended writers in our English Poesie," and declared: "In Queenes Maries time florished above any other Doctour Phaer one that was well learned and excellently well translated into English verse Heroicall certaine bookes of Virgils AEneidos. ${ }^{26}$ Arthur Hall, too, some eight years earlier opened his translation of Homer with a dedication to Sir Thomas Cecil (Lord Burghley's older, less competent son), wherein he confesses to prolonged scholarly torpor and mental disquiet, claiming, however, with some feeling that it was Phaer who finally stimulated him:

But when I lighted on M. Thomas Phaers Virgilian Englishe, quoth I, what have I done? am I become senslesse, to travaile to be laughed at, to presume, and to be scorned, and to put forth my selfe and not to be received: for I was so abashed looking upon M. Phaers Heroicall Virgill, and my Satiricall Homer, as I cried out, envying Virgils prosperitie. ${ }^{27}$

Consider also the preface of Thomas Nashe to Robert Greene's romance narrative, Menaphon (1589). Nashe, with characteristic enthusiasm, inveighed against pretences to learning in general, itemizing by contrast distinguished literary figures, Phaer among them:

Master Phaer likewise is not to be forgot in regard of his famous Virgil, whose heavenly verse had it not bin blemisht by his hautie thoghts England might have long insulted in his wit, and corrigat qui potest have been subscribed to his workes. ${ }^{28}$

Clearly, it was difficult to improve on Phaer in his own time. Indeed reprints of his texts carried on well into the succeeding seventeenth century.

But the authoritative polymath and public servant, "hautie thoghts" and all, did consciously try to settle accounts with himself late in life. On February 6, 1559, Phaer graduated M.B. from Oxford and proceeded M.D. the following month. Clearly a formality, his supplication for the bachelor's degree included Phaer's statement that "he had practised medicine for twenty years, and had made experiments about poison and antidotes." ${ }^{29}$ R.S. Roberts notes that university licences of the period, "to practise medicine throughout England," were usually granted at Oxford at the same time as the M.B. degree with the applicant nearly always already in practice. ${ }^{30}$ This was clearly the case with Thomas Phaer, Physician. As medical historian Nancy Siraisi puts it, "throughout the twelfth to fifteenth centuries (and for long thereafter), the task of acquiring medical expertise was pursued in a variety of contexts and at widely varying levels of formal organization, imtellectualization, and sophistication. Medical education was formally acquired in the university classroom or informally 
through private study or shared experience." ${ }^{11}$ Through practice, publication, and official imprimatur, Phaer seems to have involved himself in all the possibilities for gaining medical expertise.

Having concluded book five of Eneidos on May 4, 1556, Phaer mentions escaping an accident at Carmarthen which may or may not have involved his official duties there as customs searcher. ${ }^{32}$ A serious injury to his right hand sometime after April 3, 1560, ended his translating at line 298 of the tenth book of Eneidos, and he died later that August. His will, dated August 12th, names his wife as sole executrix and provides generously for his daughters Elynor, Mary, and Elizabeth. He also directed that his wife apply $£ 5$ to an unspecified purpose "where she doth knowe, by an appointemente betwene her and me"33 which may or may not mean auxiliary burial rites of the Roman Catholic church. Phaer also requested that his influential Protestant friend George Ferrers select a scriptural passage "graven in brasse" for his gravestone.

Phaer's Eneidos, however, lived on. According to his literary executor, William Wightman, Phaer requested that the second edition of his Eneidos be dedicated to the powerful, rising Protestant politician Sir Nicholas Bacon, Elizabeth's Lord Keeper of the Great Seal. Consequently, in 1562 Wightman saw Phaer's nine-book Eneidos through the press: "The Nyne Fyrst Bookes of the Eneidos of Virgil converted into Englishe vearse by Thomas Phaer Doctour of Phisike, with so muche of the tenthe Booke as since his death coulde be founde in unperfit papers at his house in Kilgarran forest in Penbroke shyre." In the dedication, Wightman is as forceful as he is personal:

Whilest God gave lyfe and health to Thomas Phaer Doctour of Phisike, I had some moore frendly familiaritie with him then moste men had. In whych respect he did before his last departynge downe from hence into Penbroke shire of speciall trust leave in my handes the eyght ant nynth bookes of Virgilles Eneidos, by him translated into Englyshe verse. And promised to use all hys possible diligence for the finishing of the other three bookes then utterly unbegonne: Declarynge moreover unto me that hys verye mynde and purpose was not onely to prynt the former part agayne for reformation of some faultes overslypt upon the first impression, but also havyng finished the same to dedicate the whole worke unto your Lordship, whome he tooke for a speciall Patrone and frendly favorer bothe of hym and hys doings. Albeit, it pleased God to prevent hym by death so as he coulde not make an ende thereof: yet since he lyked to commit these two bookes into my handes onely. The foarce of death shall not be able through my default to make hys worke dye: Neither shall hys good entent be frustrate in makyng your lordship the Patrone thereof $\left({ }^{*} 2^{r}\right)$. 
I quote the passage at length because the personal tone of Wightman's preface is so suggestive. It is here especially that we can discern the personal commitment, the demands and urgency of an academic so hopeful of his work and concerned with its success that he entrusts it to official channels for the purposes of correction and publication. As ever, he seeks perfection of detail coupled with the assertion of English. And in seeking the patronage of Bacon, Phaer clearly sought to ensure that his Eneidos would be facilited through the patronage of political ascendancy.

A university man himself, Sir Nicholas Bacon had certainly achieved prominence as outspoken Protestant parliamentarian during Phaer's last term as an M.P. in 1559. If, as Wightman declares, Phaer insisted on naming Bacon as patron, his public sympathies had changed from the dedication of the first edition to Queen Mary, "my moste soverain good Ladie, and onely redoughted maistresse" (Eneidos 1558, A2r). But Phaer, like his earliest patron William Paulet Marquess of Winchester, assured himself of survival by staying in the political middle. (Paulet, questioned years later about his ability to maintain top-level influence at the courts of Henry VIII, Edward VI, Mary, and Elizabeth, could assert jocularly that he was "sprung from the willow, not from the oak" 34 ). But the "middle" is a position from which to move with flexibility. To remain neutral is to remain powerless. Doubtless Phaer had learned this political lesson at Westminster at the same time as he had also learned the most effective channels of political facilitation. It comes as no surprise then that Phaer's, like many English families of the period, had daughters named both Mary and Elizabeth.

Wightman takes personal pains to show how Phaer's Eneidos consumed his attentions to the end, declaring:

Marie it should appeare by the two verses in the ende of this booke by hym translated upon his death bed the very day before he dyed, which he sent unto me subscribed with his left hand (the use of the right hande beyng taken away, through the hurte whereof he dyed) that he had gone so much further as those verses be in Virgilles tenth booke $\left({ }^{*} 2^{v}\right)$.

And those final verses? Wightman sees to it that they are printed at the conclusion for the sake of their appropriateness:

Ech mans day stands prefixt, time short \& swift with cureles bretche

[I]s lotted al mankind, but by their deedes their fame to stretche That privilege vertue gives $\left(\mathrm{Gg} 3^{r}\right)$. 
These lines from the Aeneid (10.479-81) were respectfully incorporated wordfor-word by Thomas Twyne in completing the translation. ${ }^{35}$ Phaer's linguistic expertise and power as cultural communicator lived on.

Wightman's additional biographical detail of the untimely circumstance of Phaer's death is touching: the "hurte whereof he dyed" most likely involving a fall from a horse, as suggested in Sir Thomas Chaloner's "Epitaph on Thomas Phaer, physician":

Phaer, right worthy he of long drawn years, Alas, hath perished by untimely fate:

The sword of Jove - and who shall 'scape his doom? His blood hath spilt, hard fault of luckless gait. ${ }^{36}$

But Phaer's life and work is difficult to condense into such clumsy elegiacs or to consider as biographically described by the posthumous praise of William Wightman or Barnabe Googe or William Webbe or Thomas Churchyard among the others previously quoted. Churchyard is especially suggestive in his preface to Skelton's Works where, lauding the vernacular usage of Langland, Chaucer, and Surrey, he declares: "And Phaer did hit the pricke, / In thinges he did translate." ${ }^{17}$ Clearly Phaer was on target and in the bull's eye of English literary expertise and cultural assertion in the early modern period, a central position easily overlooked by surveyors such as C.S. Lewis earlier this century. According to Lewis's backhanded praise, Phaer was "very much the best" of the Drab Age translators in English. ${ }^{38}$ But such a cursory appraisal misses the point of Phaer's real significance, a significance that is cultural as much as it is literary, and which involves English as asserted medium as much as it involves any specific literary title or translation.

Phaer's influence privileges the assertion of English in secular Tudor thought and education. Such influence leaves its traces in published texts and modes of consciousness. Nothing else remains to be excavated. According to medical historian George Frederic Still, even Phaer's memorial at Cilgerran is gone now along with the memorial brass he ordered and the very churchyard in which his body was interred. ${ }^{39}$ What remains is his multi-talented contribution to learning and letters in his own time, combining disciplines and translating them for popular edification. In this effort Phaer's Boke of Chyldren represents a transformative moment, emerging as it does from the authoritarian otherness of a translated medical text to stand on its own as an asserted and original English text of vernacular practicality. As spelled out in his preface to The Boke of Chyldren, Phaer declares himself to be determined "to shewe the 
remedies that god hath created for the use of man, to distribute in englyshe to them that are unlearned, parte of the treasure that is in other languages" (p. 13). These "other languages" include the languages of law, of Latin, of parliamentary debate, of medical inquiry, of the human body itself. Phaer is a Tudor intellectual who purposely breaks ranks with received channels of Latin authority to branch out in a variety of disciplines through the assertion of vernacular English. He is not martyred for a cause like Tyndale or More; he is not a jolting original like Ralegh or Marlowe, or even a celebrated pedagogue like Roger Ascham. Rather, Thomas Phaer represents cultural mobilization, asserting and insisting upon English as valued communication in Tudor England. And in so doing, he registers himself as a significant agent of cultural change.

\section{University of Alberta}

\section{Notes}

1. Quoted from John Foxe, Acts and Monuments, ed. Josiah Pratt, 8 vols. (London: George Seely, 1870), 5: 117, by Stephen Greenblatt, Renaissance Self-Fashioning: From More To Shakespeare (Chicago: University of Chicago Press, 1980), p. 106. Rooted in history and anthropology and the interpretation of signs across culture, Greenblatt's cultural poetics influences my approach throughout. Two other authors are especially informative for my purposes: Michel Foucault, The Archaelogy of Knowledge and The Birth of the Clinic, trans. A.M. Sheridan Smith (London: Tavistock, 1972 \& 1973); and M.M. Bakhtin, The Dialogic Imagination, trans. Caryl Emerson and Michael Holquist (Austin: University of Texas Press, 1981).

2. Foxe, Acts and Monuments, 5: 127.

3. Thomas Phaer, The Boke of Chyldren, ed. A.V. Neale and Hugh R.E. Wallis (Edinburgh: E \& S Livingstone, 1955), p. 13. Unless noted otherwise, I will quote Phaer's Boke of Chyldren from the Neale and Wallis text, a text concerning which I have some scruples. When quoting from any old-spelling text, I silently expand archaic contractions and regularize the use of all $i / j$ and $u / v$ reversals as well as the use of long $s$.

The Boke of Chyldren itself first appeared in print along with Phaer's translation of Jehan Goeurot, The Regiment of Lyfe (London, 1544; STC 11967). Two other texts appear in the compendium: Phaer's A Declaration of the Veynes and A goodly Bryefe Treatise of the Pestylence. Phaer's other publications include: A Newe Boke of Presidentes (London, 1543; STC 3327); The Seven First Bookes of the Eneidos of Virgill (London, 1558; STC 24799); and The Nyne Fyrst Bookes of the Eneidos of Virgil (London, 1562; STC 24800).

4. Anthony à Wood, Athenae Oxonienses I (1813; rpt. New York: Johnson Reprint Corp, 1967), p. 315.

5. Greenblatt, p. 9. 
6. See Elizabeth L. Eisenstein, The Printing Press as an Agent of Change, 2 vols. (Cambridge: Cambridge University Press, 1979). Other volumes that have influenced my direction include: Arthur B. Ferguson, The Articulate Citizen and the English Renaissance (Durham: Duke University Press, 1965); Antonia McLean, Humanism and the Rise of Science in Tudor England (London: Heinemann, 1972); Lawrence Stone, The Causes of the English Revolution, 1529-1642 (London: Routledge \& Kegan Paul, 1972); and Alan G.R. Smith, The Emergence of a Nation State: The Commonwealth of England 1529-1660 (London: Longman, 1984).

7. See Paul Slack, "Mirrors of Health and Treasures of Poor Men: The Uses of the Vernacular Medical Literature of Tudor England," Health, Medicine and Mortality in the Sixteenth Century, ed. Charles Webster (Cambridge: Cambridge University Press, 1979), p. 248. Phaer's sense of public service is mentioned also by Ted Brown, "Word Wars: The Debate over the Use of the Vernacular in Medical Writings of the English Renaissance," Texas Studies in Literature and Language, 37 (1995): 98-113.

8. Sir Thomas Elyot, The Castel of Helth (London, 1541; STC 7644), A4v .

9. To date, the only extended biographical work on Phaer is by Sidney Lee, "Phaer, Thomas," DNB (London: Smith, Elder \& Co., 1909), XV, pp. 1026-27. See also my note on Phaer's contemporary reputation, "Thomas Phaer and the London Literati," Notes and Queries, 239 (1994): 33-35.

10. Seven Bookes, Eneidos, A2r.

11. See Natura Brevium, Newly Corrected in Englysshe (London, 1530?; STC 18402.5).

12. Boke of Presidentes, A2v.

13. See W.J. Jones, The Elizabethan Court of Chancery (Oxford: Clarendon, 1967), pp. 63-64.

14. Thomas Fuller, History of the Worthies of England (London, 1662; Wing F2440), p. 12.

15. STC (2nd. ed.) records a copy in the Library of the Royal College of Physicians of London, but a letter dated 14 January 1997 from Geoffrey Davenport, Librarian of the Royal College of Physicians, declares the attribution to be an error.

16. Regiment of Lyfe, $\mathrm{L}^{\mathrm{v}}$.

17. See respectively: John Ruhräh, Pediatrics of the Past (New York: Paul B. Hoeber Inc., 1925), p. 147; and Steven Lally, ed. The "Aeneid" of Thomas Phaer and Thomas Twyne (New York: Garland, 1987), p. xiv.

18. See Journals of the House of Commons I, 1547-1628 (London: House of Commons, 1803), pp. 3, 4 .

19. See the Calendar of Patent Rolls 1553 (London: H.M. Stationery Office, 1926), p. 387.

20. S.T. Bindoff, The House of Commons 1509-1558 (London: Secker \& Warburg, 1982), I, p. 271.

21. See Robert S. Gottfried, Doctors and Medicine in Medieval England 1340-1530 (Princeton: Princeton University Press, 1986), p. 262. 
22. See Bindoff, House of Commons III, p. 103.

23. Lally, p. xii.

24. See Phaer's preface to Jacopo di Porcia's The Preceptes of Warre, trans. Peter Betham (London, 1544; STC 20116), A7v.

25. Lily B. Campbell, ed., The Mirror for Magistrates (1938; rpt. New York: Barnes \& Noble, 1960), p. 131.

26. George Puttenham, The Arte of English Poesie, ed. Edward Arber (London: Constable and Co.,1906), pp. 73, 75.

27. Arthur Hall, Ten Books of Homers Iliades, translated out of the French (London, 1581; STC 13630), $\mathrm{A3}^{\mathrm{v}}$.

28. The Life and Complete Works in Prose and Verse of Robert Greene VI, ed. Alexander B. Grosart (New York: Russell \& Russell, 1964), p. 20.

29. Lee, $D N B$, p. 1026.

30. See R.S. Roberts, "The Personnel and Practice of Medicine in Tudor and Stuart England. Part I: The Provinces,"Medical History, 6 (1962): 363-82.

31. Nancy Siraisi, Meddieval \& Early Renaissance Medicine (Chicago: University of Chicago Press, 1990), p. 50.

32. Bindoff, III, p. 103.

33. Peter Cunningham, “The Will of Thomas Phaer," The Shakespeare Society's Papers, 4 (1849): 4.

34. See James Tait, "Paulet, William," DNB (London: Smith, Elder \& Co., 1909), XV, pp. 53739. See also William Seymour, Ordeal by Ambition: An English Family in the Shadow of the Tudors (London: Sidgwick \& Jackson, 1972), p. 167.

35. Lally, p. xxxviii.

36. See George Frederic Still, The History of Paediatrics (1931; rpt. London: Dawsons, 1965), p. 127.

37. See the preface to John Skelton's Pithy, Pleasant, and Profitable Works (1568; rpt. Menston, Yorks.: Scolar Press, 1970). See also Barnabe Googe, "An Epitaph Of Master Thomas Phaer," in Selected Poems of Barnabe Googe, ed. Alan Stephens (Denver: Alan Swallow, 1961), p. 25; and William Webbe, A Discourse of English Poetrie (London, 1586; STC 25172), C3-C4r.

38. C.S. Lewis, English Literature in the Sixteenth Century, Excluding Drama (Oxford: Clarendon, 1954), p. 248.

39. See Still, History of Paediatrics, p. 125. A tablet commemorating Phaer was erected at Cilgerran in 1986. See John Cule, "Thomas Phaer MD of Cilgerran (1510-1560)," Medical History, 30 (1986): 90-91. 